\title{
FEMINIST PERSPECTIVES ACROSS THE BOARD
}

\author{
BARBARA FRANCHI
}

SCHOOL OF ENGLISH, UNIVERSTTY OF KENT

Natália da Silva Perez

Institute of Theatre Studies, Freie Universttät Berlin / Centre for Medieval \& Early Modern Studies, University of Kent

$\mathrm{T}$ he f-word used to be inappropriate for polite company, but today nobody seems afraid to say it, loud and proud. Hollywood stars and world-famous pop singers can openly claim to be feminists; it is now acceptable for mainstream celebrities to emulate that which more radical independent feminist artists have been doing for the past few decades. This gradual mainstreaming of feminism, facilitated in part by easier and wider access to communication technology, is reflected all over mass media. The last couple of years have also seen a number of high-profile female celebrities engaging in feminist political action. When Angelina Jolie and Emma Watson are UN ambassadors in projects that aim to promote the emancipation of women worldwide, when pop singer Beyoncé openly declares that "we have a way to go [to achieve equality] and it's something that's pushed aside and something that we have been conditioned to accept,'(Vena, 2013) their voices are heard by a wider audience, one that might not have been reached by the voices of activists and scholars who have for decades denounced the problems caused by gender discrimination.

But there are downsides to focusing only on pop feminism. As feminism gains traction as a mainstream idea, its uncomfortable corners and edges get sanded away. Pop feminism often remains limited to European and North American values, constrained within capitalist and neoliberal logic. When Charlize Theron, spokesperson of the UN-funded StopRapeNow Campaign, raises her voice and crosses her arms to fight against rape as a weapon of war, does it drown out the actual demands of rape victims in conflict zones? Echoing what Gayatri Chakravorty Spivak has criticized since the 1980s in her famous essay 'Can the Subaltern Speak?', feminist human rights scholar Karen Engle questions to what extent the "big business of white female celebrities saving black women from black men" can empower their "less fortunate sisters."(Engle, 2014) Feminist writer Mia McKenzie provides an even more blunt and concise formulation of the problems with a one-size-fits-all type of feminism: it "creates a false narrative that we're all hurt in the same ways and at the same degrees by the evils of gender inequality."(McKenzie, 2014)

A case in point is the growth of internationally-focused activist movements fighting violence against women or defending women's rights to equality. For example, One Billion Rising, an event launched by activist and Vagina Monologues author Eve Ensler, called millions of women,

\section{Corresponding editors:}

Barbara Franchi, Email: b.franchi@kent.ac.uk 
men, boys and girls around the world to go out into the street and dance to the rhythm of a song called "Break the Chain." It generated thousands of posts on social media, millions of Youtube views, and a fair bit of feel-good media coverage. Using awareness-raising as a barometer, the event was a great success-but if it becomes an end in itself, for example by privileging spectacle over support for local action, its impact on the actual safety of vulnerable women is diluted.

This special issue of Contention refrains from presenting feminist protest, or the feminist movement, as one unified, cohesive entity. Rather, it seeks to offer up a variety of feminist approaches to different areas of activism, research, critical thinking, and knowledge production. We embrace feminisms in the plural, not as a move towards unmoored relativism, but as affirmation that problems — and solutions — are never monolithic. Neither Beyoncé's feminism nor Bella Abzug's is the right one for every time and place, and only by embracing diversity within feminism can we hope to address the diverse types of gender-based oppression still present in the world.

The authors in this volume have taken questions of gender very seriously, but have also committed to intersectional analysis: they have grounded their research practices and writing strategies in the specific contexts they examine, and situated themselves within that context. Their articles provide five concrete instances of engagement with feminist questions, in disciplines ranging from literary analysis to social sciences. Beyond emphasizing the need for a variety of strategies, the present collection of essays also exemplifies guidelines for action which can be built upon in the future. In other words, the scholarship presented here does not seek only to bring attention to different instances of gender inequality, but also to help us take the next step, by demonstrating individual approaches to tackling these complex problems.

The first article presents a discussion of the 2007 referendum on abortion legislation in Portugal. By looking at psychosocial variables such as gender, religious practice, sexual attitudes, political orientation, and attitudes regarding abortion, authors Ana Figueiredo and Jorge Silva compared voting intention and voting behaviour among Portuguese youth. Their findings indicate that, though abortion is a gendered health issue, gender did not affect opinion formation on the subject. Opinions were, however, influenced by the other examined psychosocial variables.

Ola Abdalkafor's article focuses on the contexts of Egypt, Syria, and Libya to formulate a hypothesis explaining the purported absence of Arab women in social and political activism. She uses historical and literary analysis to define political rape as tool of "punishment during political turmoil" and subsequently deploys the term to discuss the relationship between Western feminists and Arab women. She contends that ethical responsibility, as formulated by Spivak, is the only way for the silence of women vulnerable to political rape to not be equated too easily with passivity.

Using notions of autobiography and testimony to analyse two Egyptian women's blogs, Sophia Brown's article tackles the other side of the coin. Brown discusses Western media's tendency to simplify the role of women and of the internet in the Arab uprisings of 2011. By considering the issue of solidarity as it is portrayed in these two blogs, she questions Western ways of framing the impact of the digital revolution in the democratisation of protests, and exposes contradictions inherent in many formulations used by Western media.

Moving to a more utopian register, Sheila Malone's contribution analyses the post-feminist strategies of two fictional characters, Kino and Lisbeth (from the Japanese anime series Kino's Journey and the Swedish film series Girl with the Dragon Tattoo, respectively). Their punk dress code and their use of motorcycles are understood as aesthetic choices that seek to erase gender by replacing it with androgyny. For Malone, in a post-feminist imaginary, androgyny signals the characters' reclaiming of power within a male-dominated social context, rather than their desire 
to become another sex.

Finally, Iain MacKenzie and Hollie MacKenzie trace connections between artistic practice and political theory through the work of Deleuze, Guattari and Irigaray. In their article, they reformulate the ontological nature of art as that which makes a difference in the world, disrupting the masculinist conception that places art under the dogmatic judgment of the thinking subject. Thus, they manage to articulate both feminist artistic practice and critical poststructuralist philosophy as avenues to challenge the dominance of the male-centred metaphors that inform our intellectual activity. Allowing space for difference and imagination surfaces as a crucial aspect of feminist practice.

We hope that, in what follows, the reader will be convinced that feminism is an important mental attitude that anyone can engage with in their practices of knowledge making and their everyday interactions. This is in contrast with approaches that might use 'gender' or 'woman' as add-on categories of analysis, without deeper change to their ordinary practice. Because ethics is at the heart of any genuine engagement with feminism, and given the non-normative definition of 'woman' that we seek to promote, the only possible way to address issues of gender is for feminism(s) to reflect the complexity and diversity of women's lived experience. 


\section{References}

Engle, K. (2014). The Grip of Sexual Violence: Reading UN Security Council Resolutions on Human Security. Presented at the Feminist Theory Workshop, Duke University.

McKenzie, M. (2014, September 24). Why I'm Not Really Here For Emma Watson's Feminism Speech At the U.N. Retrieved from http:// www.blackgirldangerous.org/2014/09/imreally-emma-watsons-feminism-speech-u-n/

Spivak, G. C. (1988). 'Can the Subaltern Speak?' In C. Nelson, \& L. Grossberg (Eds.), Marxism and the Interpretation of Culture (pp. 271-331). Basingstoke: Macmillan Education.

Vena, J. (2013, April 3). Beyoncé Considers Herself A "Modern-Day Feminist." MTV News. Retrieved from http://www.mtv.com/ news/1704878/beyonce-feminist-vogue-uk/ 